\title{
LYOPHILIZATION OF TRICHOPHYTON VERRUCOSUM ORGANISMS
}

\author{
A. RYBNIKÁR̆ \\ Bioveta, 68323 Ivanovice na Hané \\ Received fanuary 16, 1980
}

\begin{abstract}
Rybnikár̆, A.: Lyophilization of Trichophyton verrucosum organisms. Acta vet. Brno, 50, 1981: 73-77.

The effect was studied of lyophilization on the viability of Trichophyton verrucosum microorganisms and the percentage of their survival in a lyophilized condition after long-term storage. The amount of surviving $T$. verrucosum elements was found to range from $27 \%$ to $87 \%$ (on average $54 \%$ ) as compared with the initial amount before lyophilization. After six months of storage in darkness at $4{ }^{\circ} \mathrm{C}$ nearly $100 \%$ of the microorganisms were found to survive, after 12 months 90.5 to $98.5 \%$, and after $2-3$ years approximately $80 \%$ of the $T$. verrucosum microorganisms. The rate of decrease of the viability of lyophilized $T$. verrucosum elements is probably associated with the residual humidity of the lyophilized substance.
\end{abstract}

Lyophilized substance, viability, residual humidity.

From numerous literary data it is evident that the main originator of cattle trichophytosis in Czechoslovakia and abroad is the dermatophytic fungus Trichophyton verrucosum Bodin, 1902 (Čuturić 1968; Refai et al. 1976; Dobšinský et al. 1976; Sarkisov 1976; Pavlas et al. 1979). The resistance of the parasitic form of this species against disinfection means and against unfavourable life conditions is well known (Tkáčik 1969; Ladzianska and Halaša 1975). In spite of this fact it is very difficult to maintain this fungus under laboratory conditions. When maintaining the $T$. verrucosum culture in vitro for a longer length of time unconstant modification and hereditary mutations are formed. From this point of view the method of lyophilization seems to be more suited for long-term preservation of $T$. verrucosum strains. In the literature available data about the effect of lyophilization on the viability of $T$. verrucosum microorganisms are given only in the studies of the Polish author Wawrzkiewicz (1976). When using $50 \%$ normal inactivated calf serum as a protective lyophilic medium the above mentioned author was successfull in maintaining the $T$. verrucosum lyophilized substance in a living and unchanged condition for a period of one year. However, lyophilization caused a more than 100-fold decrease of the number of living microorganisms as compared with the initial amount, and this represents considerable losses. The aim of the present study was to determine the number of surviving $T$. verrucosum organisms after lyophilization and after a three-year storage using the author's own method of lyophilization.

\section{Materials and Methods}

The Trichophyton verrucosum Bodin (1902) culture was cultivated in darkness at a temperature of $28^{\circ} \mathrm{C}$ on malt- agar. After 14-16 days of growth it was homogenized in saline. Into a thus prepared homogenized substance the protective lyophilic medium $(5 \%$ of gelatine and $7.5 \%$ of saccharose) was added in the same amount as the saline. A sample was taken from the suspension obtained and the living organisms of $T$. verrucosum were counted using the plate dilution method; the numbers of microconidia were assessed microscopically. After taking the sample the suspension was divided in the amount determined into penicillin vials and freezed to $-50^{\circ} \mathrm{C}$. Drying was performed in a KS-30 lyophilization apparatus for 24 to 48 hours. Vials with the dried substrate were closed with rubber caps in a vacuum. In the lyophilized substance obtained the residual humidity was determined and the numbers of living fungi were counted using the plate method.

When determining the number of living $T$. verrucosum microorganisms using the plate method 
the lyophilized substance was diluted with saline in the same ratio as the homogenized sample before lyophilization. In both cases the samples were gradually diluted to a concentration of $10^{-5}$ and $10^{-6}$. From each of these dilutions $0.5 \mathrm{~cm}^{3}$ was transferred onto Petri dishes with maltagar and after 7 days of incubation at $28^{\circ} \mathrm{C}$ in darkness the $T$. verrucosum colonies grown were counted. From the results obtained the number of living $T$. verrucosum organisms in $1 \mathrm{~cm}^{3}$ of diluted sample was counted.

The number of $T$. verrucosum microconidia in the sample before lyophilization was determined microscopically in a Bürker's chamber.

The residual humidity of the lyophilized substance was assessed from the difference in its weight after lyophilization and after drying at $105^{\circ} \mathrm{C}$ in a drier for a period of one hour.

\section{Results}

A survey of the effect of lyophilization on the viability of $T$. verrucosum microorganisms is given in Tab. 1. This table also gives the results of microscopical determination of the number of microconidia in the majority of samples before lyophilization. The amount of $T$. verrucosum elements surviving the process of

Table 1

Effect of lyophilization on viability of Trichophyton verrucosum organisms

\begin{tabular}{|c|c|c|c|c|}
\hline \multirow{2}{*}{$\begin{array}{l}\text { Sample } \\
\text { No. }\end{array}$} & \multirow{2}{*}{$\begin{array}{l}\text { No. of microconidia } \\
\text { in } 1 \mathrm{~cm}^{3} \text { of sample } \\
\text { before lyophilization }\end{array}$} & \multicolumn{2}{|c|}{$\begin{array}{l}\text { No. of viable T. verrucosum } \\
\text { in } 1 \mathrm{~cm}^{3} \text { of sample }\end{array}$} & \multirow{2}{*}{$\begin{array}{l}\text { Per cent of surviving } \\
\mathrm{T} . \text { verrucosum after } \\
\text { lyophilization }\end{array}$} \\
\hline & & before lyophilization & after 1yophilization & \\
\hline $\begin{array}{r}1 \\
2 \\
3 \\
4 \\
5 \\
6 \\
7 \\
8 \\
9 \\
10 \\
11 \\
12 \\
13 \\
14 \\
15 \\
16 \\
17 \\
18 \\
19 \\
20 \\
21 \\
22 \\
23 \\
24 \\
25 \\
26 \\
27 \\
28 \\
29 \\
30 \\
31 \\
32 \\
23 \\
34 \\
35 \\
36 \\
37 \\
38 \\
39\end{array}$ & $\begin{array}{r}1,296,000 \\
35,600,000 \\
24,320,000 \\
29,700,000 \\
35,100,000 \\
23,625,000 \\
17,600,000 \\
21,600,000 \\
\\
12,210,000 \\
11,070,000 \\
4,880,000 \\
5,490,000 \\
2,950,000 \\
6,480,000 \\
12,560,000 \\
10,000,000 \\
7,720,000 \\
12,190,000 \\
9,760,000 \\
13,155,000 \\
\\
11,895,000 \\
\end{array}$ & $\begin{array}{r}23,300,000 \\
46,570,000 \\
2,100,000 \\
35,000,000 \\
25,575,000 \\
11,067,000 \\
38,700,000 \\
28,975,000 \\
32,950,000 \\
16,325,000 \\
26,533,000 \\
13,180,000 \\
14,325,000 \\
10,075,000 \\
6,175,000 \\
7,800,000 \\
4,530,000 \\
9,970,000 \\
11,900,000 \\
13,800,000 \\
9,150,000 \\
12,305,000 \\
11,640,000 \\
25,750,000 \\
26,050,000 \\
18,300,000 \\
32,225,000 \\
18,800,000 \\
14,700,000 \\
32,570,000 \\
36,370,000 \\
20,000,000 \\
22,000,000 \\
18,800,000 \\
17,360,000 \\
53,000,000 \\
30,000,000 \\
18,835,000 \\
26,370,000\end{array}$ & $\begin{array}{r}17,600,000 \\
28,300,000 \\
1,180,000 \\
22,825,000 \\
18,150,000 \\
7,350,000 \\
21,525,000 \\
24,450,000 \\
20,275,000 \\
10,540,000 \\
13,280,000 \\
10,425,000 \\
8,450,000 \\
4,200,000 \\
3,475,000 \\
3,830,000 \\
1,925,000 \\
4,325,000 \\
6,930,000 \\
7,000,000 \\
3,800,000 \\
7,000,000 \\
5,830,000 \\
15,530,000 \\
14,330,000 \\
16,000,000 \\
10,330,000 \\
9,530,000 \\
7,030,000 \\
14,350,000 \\
11,200,000 \\
11,600,000 \\
15,600,000 \\
11,900,000 \\
11,400,000 \\
18,900,000 \\
8,200,000 \\
5,330,000 \\
8,900,000\end{array}$ & $\begin{array}{l}75.5 \\
60.8 \\
56.2 \\
65.2 \\
71.0 \\
66.4 \\
55.6 \\
84,4 \\
61.5 \\
64,6 \\
50.1 \\
79.1 \\
59.0 \\
41.7 \\
56.3 \\
49.1 \\
42.5 \\
43.4 \\
58.2 \\
50.7 \\
41.5 \\
56.9 \\
50,1 \\
60.3 \\
55.0 \\
87.4 \\
32.1 \\
50.7 \\
47.8 \\
44.1 \\
30.8 \\
58.0 \\
70.9 \\
63.3 \\
65.7 \\
35.7 \\
27.3 \\
28.3 \\
33.8\end{array}$ \\
\hline $\begin{array}{l}\text { Mean } \\
\text { values }\end{array}$ & $17,008,000$ & $21,104,000$ & $11,354,000$ & 53.8 \\
\hline
\end{tabular}


Table 2

Survival of $T$. verrucosum in lyophilized form kept in the dark at $4^{\circ} \mathrm{C}$ for $6,12,18,14$ and 36 months

\begin{tabular}{|c|c|c|c|c|c|}
\hline $\begin{array}{c}\text { Sample } \\
\text { No. }\end{array}$ & $\begin{array}{l}\text { No. of viable } T \text {. verru- } \\
\text { cosum in } 1 \mathrm{~cm}^{3} \text { of } \\
\text { sample before } \\
\text { lyophilization }\end{array}$ & $\begin{array}{c}\text { Lyophilizate } \\
\text { moisture } \\
\%\end{array}$ & $\begin{array}{c}\text { Storage of } \\
\text { lyophilizate } \\
\text { (months) }\end{array}$ & $\begin{array}{l}\text { No. of viable } T \text {. verru- } \\
\text { cosum in } 1 \mathrm{~cm}^{3} \\
\text { of sample after } \\
\text { the storage time }\end{array}$ & $\begin{array}{l}\text { Per cent of } \\
\text { surviving } T \text {. ver- } \\
\text { rucosum } \\
\text { organisms }\end{array}$ \\
\hline $\begin{array}{l}40 \\
41\end{array}$ & $\begin{array}{r}5,330,000 \\
12,400,000\end{array}$ & $\begin{array}{l}2.04 \\
1.44\end{array}$ & $\begin{array}{l}6 \\
6\end{array}$ & $\begin{array}{r}5,300,000 \\
12,230,000\end{array}$ & $\begin{array}{l}99.4 \\
98.6\end{array}$ \\
\hline $\begin{array}{l}42 \\
43 \\
44 \\
45\end{array}$ & $\begin{array}{r}5,800,000 \\
10,425,000 \\
3,830,000 \\
2,740,000\end{array}$ & $\begin{array}{l}1.29 \\
1.99 \\
2.45 \\
2.55\end{array}$ & $\begin{array}{l}12 \\
12 \\
12 \\
12\end{array}$ & $\begin{array}{l}5,250,000 \\
9,900,000 \\
3,680,000 \\
2,700,000\end{array}$ & $\begin{array}{l}90.5 \\
95.0 \\
96.1 \\
98.5\end{array}$ \\
\hline $\begin{array}{l}46 \\
47 \\
48 \\
49\end{array}$ & $\begin{array}{r}2,625,000 \\
17,900,000 \\
11,150,000 \\
7,700,000\end{array}$ & $\begin{array}{l}1.93 \\
3.02 \\
3.44 \\
2.80\end{array}$ & $\begin{array}{l}18 \\
18 \\
18 \\
18\end{array}$ & $\begin{array}{r}2,400,000 \\
12,670,000 \\
8,675,000 \\
6,770,000\end{array}$ & $\begin{array}{l}91.4 \\
70,8 \\
77.8 \\
87.9\end{array}$ \\
\hline $\begin{array}{l}50 \\
51 \\
52\end{array}$ & $\begin{array}{r}7,000,000 \\
11,600,000 \\
15,600,000\end{array}$ & $\begin{array}{l}3.10 \\
3.42 \\
2.46\end{array}$ & $\begin{array}{l}24 \\
24 \\
24\end{array}$ & $\begin{array}{r}5,350,000 \\
8,500,000 \\
12,700,000\end{array}$ & $\begin{array}{l}76.4 \\
73.3 \\
81.4\end{array}$ \\
\hline $\begin{array}{l}53 \\
54\end{array}$ & $\begin{array}{l}5,600,000 \\
2,200,000\end{array}$ & $\begin{array}{l}2.54 \\
3.12\end{array}$ & $\begin{array}{l}36 \\
36\end{array}$ & $\begin{array}{l}4,600,000 \\
1,725,000\end{array}$ & $\begin{array}{l}82.1 \\
78.4\end{array}$ \\
\hline
\end{tabular}

lyophilization in the individual samples ranged between $27.3 \%$ and $87.4 \%$ $(54 \%$ on average) of the initial number before lyophilization.

Tab. 2 shows the results of the survival of $T$. verrucosum microorganisms maintained for a long period in a lyophilized condition in darkness at $4{ }^{\circ} \mathrm{C}$. After 6 months of storage of the lyophilized substances the viability of $T$. verrucosum remained virtually unchanged. After one year of maintaining the microorganisms in a lyophilized condition $90.5-98.5 \%$ of the initial number before lyophilization survived. When storing for a period of more than one year the number of living $T$. verrucosum elements in the lyophilized substance further decreased and after three years the number of surviving organisms ranged around $80 \%$ of the initial number. The amount of surviving T. verrucosum microorganisms was relatively lower in samples with a high residual humidity of the lyophilized substance.

\section{Discussion}

Acquiring successfull results in the lyophilization of microbiological cultures depends not only on the method of performing the individual stages of lyophilization but also on the quality of the initial biological material. From results obtained by Wawrzkiewicz (1976) it is evident that during lyophilization of $T$. verrucosum culture composed almost exclusively of mycelia the great majority of the organisms dies and the number of surviving elements is about 100 times lower as compared with the initial amount. In the present experiment the $T$. verrucosum culture to be lyophilized was composed of a great number of microconidia (see Tab. 1), a smaller part was formed by mycelium, and sporadically also chlamydospores and macroconidia occurred. From the results of the decrease of the number of living organisms after lyophilization it is evident that under the effect of lyophilization probably not only the mycelium was damaged but also a certain part of the microconidia. In spite of this fact the amount of surviving T. verrucosum microorganisms was relatively high and ranged from $27 \%$ to $87 \%$ (54 \% 
on average). These values outnumber the results given during the lyophilization of bacteria when the viability decreased mostly to 5-25\% (Sturdza et al. 1968).

In the present experiments the lyophilized substances were stored at a temperature of $4{ }^{\circ} \mathrm{C}$ in darkness because the inhibitory effect of visible light on dermatophytes is well known (Buchníček 1974). The viability of $T$. verrucosum maintained under the conditions given decreased in the course of one year only insignificantly (by 1.5 to $9.5 \%$ ). After a longer period of maintaining the lyophilized substances the number of surviving microorganisms ranged from 70-80\% up to three years of storage (the period of investigations). Besides, in samples with a higher residual humidity of the lyophilized substance the decrease of the viability of $T$. verrucosum was relatively higher.

A direct dependence between the residual humidity of lyophilized microorganisms and the percentage of their lethal damage is known from data in bacteria (Proom 1951; Sturdza et al. 1968). However, in the same way as a too high amount of residual humidity the viability of bacteria can be unfavourably affected also by excessive drying (Hutton et al. 1951). In lyophilized T. verrucosum substances with a high residual humidity in our case the germination of microconidia probably occurred and thus also a decrease of their viability during long-term storage. In the present study it was not possible to determine the precise range of residual humidity of the lyophilized substance under which the viability of the preserved $T$. verrucosum microorganisms was the highest and this problem will have to be further investigated in greater detail.

\section{Lyofilizace mikroorganismů Trichophyton verrucosum}

Byl sledován vliv procesu lyofilizace na životaschopnost mikroorganismů Trichophyton verrucosum a procento jejich přeživání v lyofilizovaném stavu při dlouhodobém skladování. Bylo zjištěno, že množství přežívajících elementů $T$. verrucosum po lyofilizaci se pohybuje od $27 \%$ do $87 \%$ (průměrně $54 \%$ ) v porovnání s výchozím počtem před lyofilizací. Po 6 měsících skladování v temnu při $4{ }^{\circ} \mathrm{C}$ prrežívalo téměř $100 \%$ mikroorganismů, po 12 měsících 90,5 až $98,5 \%$ a po 2 až 3 letech kolem $80 \%$ mikroorganismů $T$. verrucosum. Velikost snížení životnosti lyofilizovaných zárodků $T$. verrucosum pravděpodobně souvisí se zbytkovou vlhkostí lyofilizátu.

\section{Лиофилизация микроорганизмов Trichophyton verrucosum}

Проводились исследования влияния процесса лиофилизации на жизнеспособност микроорганизмов Irichophyton verrucosum и процента их переживания в лиофилизированном состоянии при длительном хранении. Было установлено, что количество переживающих элементов $T$. verrucosum после лиофилизации достигает пределов $27 \%-87 \%$ (в среднем $54 \%$ ) по сравнению с исходным количеством перед лиофилизацией. После 6 месяцев хранения в темном помещении при температуре $4{ }^{\circ} \mathrm{C}$ переживало почти $100 \%$ микроорганизмов, после 12 месяцев 90,5-98,5\% и после $2-3$ лет приблизительно $80 \%$ микроорганизмов T. verrucosum. IІонижение жизнеспособности лиофилизированных элементов $T$. verrucosum вероятно связано с остаточной влажностью лиофилизата. 


\section{References}

BUCHNÍČEK, J.: Biologische Inhibition durch Licht. Acta Univ. Olomuc., Fac. med., 71, 1974: $161-237$.

ČUTURIĆ, S.: Etiologija i raširenost govedeg lišaja na poljoprivrednim dobrima u Hrvatskoj s osvrtom na kliničku sliku bolesti. Veterin. arh., 38, 1968: 265-274.

DOBŠINSKÝ, O. - POLÁK, L. - ŠEVČ́̇K, B. - KUBÍN, I. - HARTMANOVÁ, J.: Bovine trichophytosis and the development of new antimycotic preparation in the Czechoslovak Socialist Republic. Bull. Off. int. Epiz., 85, 1976: 467-480.

HUTTON, R. S. - HILMOE, R. J. - ROBERTS, J.: Some factors that influence the survival of Bruc. abortus during freeze-drying. J. Bact., 61, 1951: 309.

LADZIANSKÁ, K. - HALAŠA, M.: Prežívanie pôvodcu trichofytiázy hovädzieho dobytka Trichophyton verrucosum Bodin, 1902, za niektorých podmienok mimo hostitelský organizmus. Veter. čas., 17, 1975: 15-19.

PAVlAS, M. - WILlOMITZER, J. - MRVA, V. - PATLOKOVÁ, V. - PROCHÁZKA, F.: Preventivní a léčebná účinnost vakcíny proti trichofytóze u skotu. Vet. Med. Praha, 24, 1979: 209-216.

PROOM, H.: Some of the factors affecting the viability of bacterial cultures subjected to the freeze-drying process. Freezing and Drying. Report of a Symposium. The Institut of Biology London, 1951: 117.

REFAI, M. - IBRAHIM, M. S. - SAIFI, A.: Über das Vorkommen von Trichophyton-verrucosum-Infektionen in Ägypten mit Hinweis auf die Behandlung mit Griseofulvin. Dtsch. tierärztl. Wschr., 83, 1976: 62-64.

SARKISOV, A. CH.: Prophylaxie spécifique de la Trichophytose des jeunes bovins. Bull. Off. int. Epiz., 85, 1976: 481-488.

STURDZA, S. A. - ARION, R. - VASILESCU, T.: Liofilizarea bacteriilor şi bazele ei xerobiologice şi criobiologice. Microbiol., Parazitol., Epidem., 13, 1968: 305-314.

TKÁČIK, S.: Účinok niektorých dezinfekčných prostriedkov na hubu Trichophyton verrucosum in vitro. Folia vet., 13, 1969: 41-49.

WAWRZKIEWICZ, K.: Liofilizacja jako metoda przechowywania szczepów Trichophyton verrucosum. Med. Wet., 32, 1976: 116-119. 